\section{E-cigarette use in air transit: self-reported data from US flight attendants}

\section{INTRODUCTION}

The purpose of this analysis was to evaluate the use of electronic cigarettes (e-cigarettes) in air transit, and to understand potential problems created by this practice for flight crew and patrons. Safety concerns around the long-term effects of ecigarette use and passive inhalation in enclosed spaces are being studied, yet ecigarettes are increasingly being used in smoke-free places. ${ }^{1}$ No studies have examined the issues of e-cigarette use in air transit.

\section{METHODS}

In 2012, we surveyed 723 flight attendants for a study on secondhand smoke and air quality in the work environment. Participants were recruited through a flight attendant union and advertisement in social media groups for flight attendants. Based on discussions with flight attendants and key informants, it was determined that eligible participants had to service a minimum of two international flights per month for at least 1 year in their current position. The study focused on US carriers but participation was open to all English-speaking flight attendants.

Participants were asked "Do you use ecigarettes? (yes or no)". Next they were asked whether they ever observed anyone using an e-cigarette in an airport or aeroplane (yes or no), and if yes, an open-ended response obtained further details on their observations of e-cigarette use. All open responses were coded using Stata to assign categories for location of observation (aeroplane, airport, other) and person observed (passenger, flight attendant, crew) and were then validated by hand to confirm that the coding system was accurate. Other information collected in the survey included demographics, smoking status and attitudes toward smoke-free policies.

\section{RESULTS}

Among responses to the e-cigarette questions, $92.4 \%$ of respondents worked for a US-based carrier, $82.4 \%$ of which were a major US carrier. A total of 39 (6.8\%) responded that they used e-cigarettes (table 1). After adjustment for age and gender, the OR for e-cigarette use was 13.6 (95\% CI 6.3 to 29.3) comparing current smokers to never smokers.

A total of $264(46.4 \%)$ respondents reported ever seeing e-cigarette use in an aeroplane or airport. Among those respondents, $41.3 \%$ reported seeing an ecigarette used in an airplane, $25 \%$ in an airport, $6.4 \%$ in both locations, and $27.3 \%$ of locations were unspecified. Within these observations of use on an aeroplane $(\mathrm{N}=109), 76.9 \%$ involved a passenger using an e-cigarette, $8.8 \%$ involved a flight attendant or crew, and $12.9 \%$ were unspecified.

Flight attendants' open responses indicated confusion among coworkers, passengers, and crew about e-cigarette usage during flights. Notable responses included:

"Pilot had [e-cigarette] onboard and demonstrated it"

"Several [flight attendants] use them inflight in bathroom (against regulations) and on the ground."

"[Passenger] was told by ticket agents it was allowed on board..."

“...Occasionally passengers will attempt to use them in the airplane and have to be told they are prohibited by the FAA."

\section{DISCUSSION}

Results suggested that flight attendant ecigarette use is similar compared to the national prevalence of $6.2 \%$ adult ever-use. $^{2}$ Flight attendants commonly witnessed e-cigarette use during flights

and gave conflicting reports about what was allowed by airlines, which indicates inadequate communication of policies to passengers and crew. Indeed, the Federal Aviation Administration (FAA), Department of Transportation (DOT) and Transportation Security Administration (TSA) do not have official policies on e-cigarette use in air travel, though the DOT did issue a Notice of Proposed Rulemaking (NPRM) in 2011 and 2013. Meanwhile, numerous domestic and international US airline companies, including United, American Airlines, Southwest, Delta and JetBlue, have begun banning e-cigarette use on a voluntary basis. ${ }^{3}$

Allowing e-cigarette use in smoke-free places undermines the denormalisation of cigarette smoking, ${ }^{4}$ particularly with respect to the milestone ban on in-flight smoking that flight attendant unions and smoke-free advocates fought incredibly hard to pass. ${ }^{5}$ The use of e-cigarettes in air transit-both on aeroplanes and in airports-must be addressed in the current policy and regulatory deliberations in the US and around the world. Given the growing evidence around passive vaping and air quality associated with e-cigarette use, ${ }^{6-8}$ banning e-cigarettes on aeroplanes and in airports is a needed step-forward for the protection of both passengers and crew.

Table 1 Flight attendant characteristics by e-cigarette use and observation of e-cigarette use

\begin{tabular}{|c|c|c|c|c|c|c|c|}
\hline & \multirow[b]{2}{*}{$\mathrm{N}$} & \multicolumn{3}{|c|}{ Do you use e-cigarettes? } & \multicolumn{3}{|c|}{$\begin{array}{l}\text { Have you ever observed a person } \\
\text { using e-cigarettes in an airport or } \\
\text { aeroplane? }\end{array}$} \\
\hline & & Yes & No & $p$ Value & Yes & No & $p$ Value \\
\hline N & 569 & 39 & 530 & & 264 & 305 & \\
\hline \multicolumn{8}{|l|}{ Sex } \\
\hline Men & 184 & 51.3 & 30.6 & $<0.01$ & 36.4 & 28.2 & 0.04 \\
\hline Women & 387 & 48.7 & 69.4 & & 63.6 & 71.8 & \\
\hline Age, years* & 569 & $39.3(11.9)$ & $42.6(11.6)$ & 0.08 & $44.1(11.1)$ & $40.8(11.9)$ & $<0.01$ \\
\hline College and more & 302 & 59.0 & 52.6 & 0.44 & 48.9 & 56.7 & 0.06 \\
\hline $\begin{array}{l}\text { Worked before in-flight } \\
\text { smoking ban }\end{array}$ & 225 & 38.5 & 39.6 & 0.89 & 48.5 & 31.8 & $<0.01$ \\
\hline \multicolumn{8}{|l|}{ Smoking status } \\
\hline Never & 385 & 33.3 & 70.2 & $<0.01$ & 63.6 & 71.1 & 0.15 \\
\hline Former & 106 & 2.6 & 19.8 & & 20.5 & 17.1 & \\
\hline Current & 78 & 64.1 & 10.0 & & 15.9 & 11.8 & \\
\hline $\begin{array}{l}\text { Agree with smoke-free } \\
\text { indoor public places } \\
\text { (including airports) }\end{array}$ & 497 & 71.8 & 88.5 & $<0.01$ & 90.9 & 84.3 & 0.02 \\
\hline $\begin{array}{l}\text { Prefer to work in a } \\
\text { smoke-free } \\
\text { environment }\end{array}$ & 515 & 79.5 & 91.3 & 0.02 & 93.9 & 87.5 & $<0.01$ \\
\hline $\begin{array}{l}\text { Believe airports need } \\
\text { additional tobacco } \\
\text { control policies }\end{array}$ & 382 & 43.6 & 68.9 & $<0.01$ & 78.4 & 57.4 & $<0.01$ \\
\hline
\end{tabular}




\section{What this paper adds}

- This paper provides data on the use of electronic cigarettes (e-cigarettes) in air transit, which is needed to inform current policy and regulatory deliberations in the US and around the world.

- Our findings show that e-cigarettes are frequently used in air transit-both on aeroplanes and in airports- by flight attendants, crew, and passengers.

- Findings also indicate confusion around knowledge and awareness of airline and federal regulations around e-cigarettes in air transit.

- These results indicate that it is urgent to take action to consistently ban these products on flights and in airports, and to implement and enforce rules.

\section{Frances A Stillman, ${ }^{1}$ Andrea Soong, ${ }^{1}$ Laura Y Zheng, ${ }^{2}$ Ana Navas-Acien ${ }^{2}$}

${ }^{1}$ Department of Health, Behavior and Society, Johns Hopkins Bloomberg School of Public Health, Institute for Global Tobacco, Baltimore, Maryland, USA

${ }^{2}$ Department of Environmental Health Sciences, Johns Hopkins Bloomberg School of Public Health, Baltimore, Maryland, USA

Correspondence to Dr Frances A Stillman, Department of Health, Behavior and Society, Johns Hopkins Bloomberg School of Public Health, Institute for Global Tobacco, 2213 McElderry Street, 4th Floor, Baltimore, MD 21205, USA; fstillm1@jhu.edu

Correction notice This article has been corrected since it was published Online First. In the Results section the sentence 'Among those respondents, $41.3 \%$ reported seeing an e-cigarette used in an aeroplane, $25 \%$ on an aeroplane...' has been

amended to 'Among those respondents, $41.3 \%$ reported seeing an e-cigarette used in an airplane, $25 \%$ in an airport...'

Contributors FAS and AN-A led the study concept and design. FAS supervised the study and oversaw the acquisition of data. AN-A had full access to all of the data in the study and takes responsibility for the integrity of the data and the accuracy of the data analysis. Authors AS, LYZ, and AN-A were responsible for the analysis and interpretation of data. FAS, AN-A, and AS drafted the manuscript and were responsible for critical revision of the manuscript. FAS obtained funding for the research. AS was responsible for administrative, technical, and material support. Al authors gave final approval of the manuscript.

Funding The work was supported by grant number 108594 from the Flight Attendant Medical Research Institute (FAMRI) to the Johns Hopkins FAMRI Center of Excellence. Co-author Laura Zheng was supported by training grant $\mathrm{T} 42 \mathrm{OH} 008428$ from the NIOSH Education and Research Center for Occupational Safety and Health. The funders had no role in the study design, collection, analysis or interpretation of data, writing of the report, nor in the decision to submit the paper for publication.

\section{Competing interests None.}

Patient consent Obtained.

Ethics approval Johns Hopkins Bloomberg School of Public Health Institutional Review Board.

Provenance and peer review Not commissioned; externally peer reviewed.

Data sharing statement We are willing to make all data available to any interested parties. Please contact corresponding author Dr Stillman for more information.

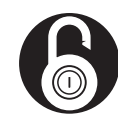

\section{OPEN ACCESS}

Open Access This is an Open Access article distributed in accordance with the Creative Commons Attribution Non Commercial (CC BY-NC 3.0) license, which permits others to distribute, remix, adapt, build upon this work non-commercially, and license their derivative works on different terms, provided the original work is properly cited and the use is noncommercial. See: http://creativecommons.org/licenses/ by-nc/3.0/

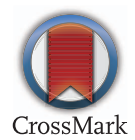

To cite Stillman FA, Soong A, Zheng $L Y$, et al. Tob Control 2015:24:417-418.

Accepted 29 May 2014

Published Online First 20 June 2014

Tob Control 2015;24:417-418.

doi:10.1136/tobaccocontrol-2013-051514

\section{REFERENCES}

1 Bertholon JF, Becquemin MH, Annesi-Maesano I, et al. Electronic cigarettes: a short review. Respiration 2013:86:433-8

2 King BA, Alam S, Promoff G, et al. Awareness and ever-use of electronic cigarettes among U.S. adults, 2010-2011. Nicotine Tob Res 2013;15:1623-7.

3 Davies A. Sorry smokers, you can't use electronic cigarettes on airplanes. Business Insider. http://www. businessinsider.com/you-cant-smoke-e-cigarettes-inplanes-2013-2. Published 27 February 2013. (accessed 9 May 2013).

4 Benowitz NL, Goniewicz ML. The regulatory challenge of electronic cigarettes. JAMA 2013;310:685-6.

5 Holm AL, Davis RM. Clearing the airways: advocacy and regulation for smoke-free airlines. Tob Control 2004;13(Suppl 1):i30-6.

6 Schripp T, Markewitz D, Uhde E, et al. Does e-cigarette consumption cause passive vaping? Indoor Air 2013;23:25-31.

7 Schober W, Szendrei K, Matzen W, et al. Use of electronic cigarettes (e-cigarettes) impairs indoor air quality and increases FeNO levels of e-cigarette consumers. Int J Hyg Environ Health doi:10.1016/ j.ijheh.2013.11.003. Epub ahead of print

8 Czogala J, Goniewicz ML, Fidelus B, et al. Secondhand exposure to vapors from electronic cigarettes. Nicotine Tob Res 2013;6:655-62. 